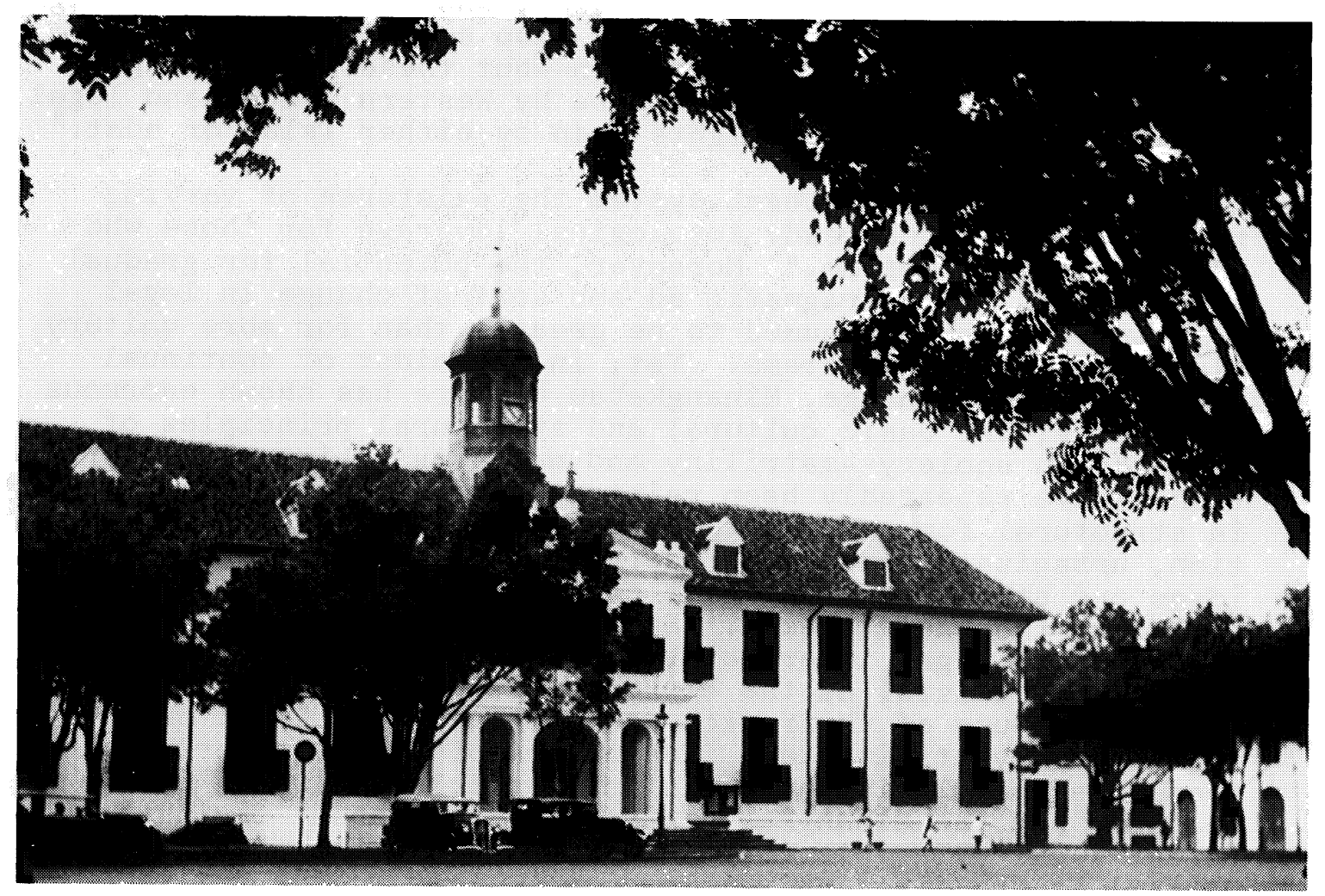

The Batavia Stadhuis (City Hall), completed in 1710. Photo: Claire Holt, 1936. 


\section{RACE AND COLOR IN COLONIAL SOCIETY: BIOGRAPHICAL SKETCHES BY A EURASIAN WOMAN CONCERNING PRE-WORLD WAR II INDONESIA*}

Translated and Edited by

Paul W. van der Veur

This confession may seem tough, mean, embittered, but it is the truth. I have bared my soul completely, putting my whole being into it and I am open and honest about everything. To answer your questions in a concise form would never do. What

* The material for this article was obtained while conducting field research on the political history of the Eurasians of Indonesia in the Netherlands from March 1952 to February 1953 on a grant from Cornell University's Social Science Research Center. To supplement library and archival research, my wife and I stayed as participant observers in one of the numerous "relocation centers" which had been set up in the Netherlands for those Eurasians who needed help in finding a job and/or a place to live. All the residents of the center were interviewed concerning a variety of matters, but of particular interest were their views concerning their past relationships with Dutchmen and Indonesians. In addition, the interviewees were asked three open-ended questions: (a) whether Eurasians considered that they had particular customs as Eurasians; (b) whether they felt there were various groups within their community, and (c) what they expected the future of their group to be.

Naturally the residents of the center received visits from relatives or friends who were already settled in the Netherlands. In discussing the study with the editor the sister of one of the relocation center women expressed the opinion that few of the residents would speak their mind to a stranger and a person of non-Eurasian extraction. I requested, therefore, that she assist me by also answering the open-ended questions mentioned above. The result was more open-ended than anticipated and is presented in the following pages.

The willingness of this Eurasian woman to give her story is obviously unusual. She was considerably less Eurasian in features and mannerism than her sister and quite tall for a Eurasian. About thirty years of age, she was married to a Dutchman with relatives in the Netherlands and had never faced the necessity of having to pass through a relocation center upon arrival in the Netherlands. In a personal note attached to her answers she apologized for having spoken her mind so openly, adding that her "own sister and husband would be shocked if they read this."

The original manuscript was written in Dutch and has been translated as faithfully as possible. Editorial additions have been placed in square brackets or in notes. 
you read here is Iiving material. But then, who is so completely without shame as I am to write this down? I have broken my bonds. Another reason is that $I$ am afraid that residing in that relocation center, you will hear only about a special group of half bloods: the lowest group, those who really warrant the designation "indolent Indo" [lazy Eurasian]. ' The person who was more Javanese than Dutch has long ago returned to Java; he, who is more European, is no longer in such centers. They are among those who are better off, who already have had success and been absorbed into Dutch society. The future of the half bloods lies here in Holland. It is to Holland that they must now open their hearts and thoughts. The Indies is something which belongs to the past. It is best to forget as quickly as possible that one is an Indo. Let the children learn in school, so that they can acquire a position here in Holland. Let them preferably marry Dutchmen. Yes, perhaps to return sometime to their own land, but then only to earn money--the greatest amount in the shortest time. Besides knowing the language and the Javanese--which will give them a head start on Dutchmen--they will have certificates for various jobs. I can see satisfaction in this for them.

Don't be annoyed by all the mistakes and interruptions in this piece. I have been writing between chores. For instance, in the middle of cleaning or doing the laundry, I'll dry my hands to scribble something down. Even at 4:00 a.m. I suddenly got up because I had a thought. This notebook is lying open the whole day with the pen next to it. The children come to interrupt and ask my attention, a neighbor drops by or visitors come. But then I return to the little room where my views are written down--or rather a part of my heart. Select from this for yourself what you can use. I have not been able to live according to rules and fixed norms; so to answer your questions exactly is not possible.

What I have written down here is not only my experience and my ideas--I am everything that others have made me and I am made up of what people gave and did to me. I have never been narrow and the things which I tell you here are not my experience alone. Others with perhaps a somewhat different temperament than mine have experienced the same. But it has been forgotten by them or hidden and pushed into the background. The "I" which I use here, therefore, is not always just me; you will learn yourself to decipher it.

I know with certainty that Indo girls, with the same intelligence and temperament as mine, felt that they were successful

1. Indo was the popular abbreviation for Indo-European. Note that, in contrast, in the English term "Eurasian" the emphasis is on the "European" rather than on the "Asian" (Indonesian) component. 
when they married a full-blood European. ${ }^{2}$ To accomplish this, all sorts of means--be they good or bad--were employed. These Indos could never be reached by you for the real answers. Some completely forgot that they had a heart, so violent was their desire to hook a Dutchman, preferably rich, and especially one desired by Dutch women. It was a short and violent race, because we had friends in China and Japan and realized that we had to get married before the war broke out. But how difficult it was to get a European. Everybody--the British, the French, and the South Africans--wanted to return to their own countries. They knew before the fighting started that the Dutch would not be able to keep Java. They were careful--or was it weariness?

I was consciously brought up for such a marriage and constantly reminded:

Be careful that you do not tan.

Oil your hair, so that it will become full and long; men like thick long hair.

Your beautiful eyes will make it easier for you to get a husband.

Fortunately, you are slender--otherwise it would be terrible--big, plump girls do not appeal to men.

Ten years old. I acquired my first knowledge about the union of man and woman when I unexpectedly entered the room of one of the servants. Later I was surprised when I noticed how many of the servants put the little boys of their mistresses to sleep by stroking.

Eleven years old. I saw how a baby was born and it left a deep impression upon me. The mother made no cry of fear. There was only the soft moaning and the quiet talk of the women around her. I sat there quietly and at that moment the desire for a child was born in me so consciously that I glowed with love and desire.

I learned to speak good Dutch--as pure as possible--to help me get a Dutch husband.

We looked up to all that was white and fair at school. The yards and gardens where the Dutch children lived remained forbidden terrain for us, yet the Dutch children played secretly with us on the street. The girls asked us how one got children and what men did, and we were more than eager to teli them. I suspect that the Dutch parents feared that we would inform their

2. The desire of Eurasian women to marry Dutchmen has been commented upon in several publications. See, for example, H. van de Wall, De Paupers (Weltevreden and Amersfoort: 1903); B. Veth, Het Leven in Nederlandsch-Indië (Amsterdam: P. V. van Kampen en zoon, 1900). 
daughters and sons too early about the facts of life. "Don't play with those Indos; they are dirty and cannot be trusted." "Don't associate with them--those girls are no good." We were considered too willing and too passionate. The Indo girl knew everything [about sex] and thought it all common and natural. The Dutch girls were reserved and blushed at any mention of a sexual subject.

[Between ages twelve and sixteen]. I had my first love. I only touched his hands. But our companionship was forbidden and he soon was sent to Bandung to study. ${ }^{3}$ I did not forget it for two years although I never heard from him again. There was no time for sorrow. I had to go on in those two years.

In school, Dutch teachers gave Dutch pupils the edge. Even with the Indo teachers this was true if the Dutch child was from very well-to-do parents. Those parents would then invite the teachers to their estates for the weekend--polishing the apple. The Indo was tolerated!

Marital difficulties, in my family, culminating in divorce, lasted for years, from my twelfth to my sixteenth year. So there was no high school education for me. I had no interests in common with children of my own age. I attended a boarding school for one year. The director was a Dutchman who--under the pretense of being fatherly--stroked, kissed and embraced us. His Indo wife looked the other way. The dormitory of the older girls was closed in the evening with a big key. I briefly came to detest all men.

When my father was awarded custody of me, I went to live with him and my three brothers in one hotel room. During that time, I was terribly ashamed that I was a girl. The relationship between Dutch girls and their brothers always surprised me. It was much more natural and affectionate. The relationship between Indo girls and their brothers was much more distant. An Indo boy was not averse to peek at his sisters and the babus [female servants]. With Dutch girl friends, I never noticed anything like that.

Dutch women were very friendly to my handsome father. I had to laugh at them inwardly. The Dutch women acted motherly to me--as if they wanted to soothe me; they did not understand that I could see through them. Daddy desired their bodies and only that. He was filled with an electricity in their company which got under my skin. I felt no hate, no surprise, no contempt; only derision, and satisfaction that it would be a Dutch woman who would lie in the arms of this dark man.

3. The writer did not mention the ethnic group to which this boy belonged. From the context it could be assumed that he was Dutch. 
I regularly saw naked Javanese and Madurese fishermen with their nets on the piers--and often took a furtive look at their sex organs. How black and small they were. I experienced no sexual urge but I thought affectionately how beautiful the supple, dark, naked bodies were. They were not so repulsive as the bodies of the Dutch. Once I watched the sunset and the drifting nets which glistened as silver. Suddenly I heard a gruff voice--a Dutchman: "It's nice to look at those naked men, isn't it?" I turned around surprised and didn't dare to look anymore. I could not find words of retort but I had not been looking at them in the way implied. I was not hurt, only surprised. After that, I avoided looking at the naked Javanese near the kali [river] or wherever they might be.

The social distance between any handsome djongos [male servant], young Javanese doctor, or [Indonesian] high school student and us was great. I had absolutely no interest in them. I found their sisters sweet and liked to be with them. Unconsciously, I felt most at home in the kitchen of our house, where, crouching in the native way, I ate rudjak, a native salad, served in a large leaf; or in the servant quarters on a rainy day, where I drank paka on the balé balé [a bamboo cot].

Along with these experiences, I heard certain phrases repeated a thousand times:

"Don't marry an Indo! Don't associate with him. Our future does not lie here, but in Europe. Repair the mistake once made by our ancestors. Create chances for your children in Holland."

Once a real katjong [Indonesian street boy], black and warm-blooded, made me wander from my objective [of finding a Dutch husband] for two months. He urged a physical relationship and marriage. Fear and surprise that this should be my future husband arose and the picture of the naked fishermen came sharply back. It was impossible and I broke off the relationship completely. "Don't think for a moment that I would like to have an Indo husband either, even though I am an Indo myself!"

At one point, I fled from my father to my mother who lived quietly and withdrawn in the garrison town of Malang in East Java. Anyone who was "in green," i.e., wearing the uniform of the soldiers of the Royal Netherlands Indies Army, and held a rank below lieutenant did not come under consideration for marriage to a well-educated Indo girl from a good home. On the street, I was accosted once by soldiers. Although it did excite me, I did not deign to answer. The Javanese, the Indos, and the military were all equally undesirable. Still, I liked to look at them secretly.

In the swimming pool I found the color of white people repulsive. The white thighs and bare, pinkish, upper part made 
me feel nauseated. The blond sun-tanned individuals with very grey-bluish eyes were the favorites. The big, handsome men were preferred.

Seventeen years old. I still had no prospect of marriage or job opportunities, so I went to Batavia [Djakarta]. I knew a little bit about many things and had the advantage of possessing a great duse of impudence. I had no fear of poverty or hunger. I was too well-bred, I felt, to be afraid of that. The average. Indo girl customarily slept on a mattress with only a little mat, ate rice with tempeh [a soybean cake] and some sajur lodeh [a vegetable dish]. If worse came to worst, she could let the babu get a rice dish without meat for her for a nickel or, with fish, for a dime at the warong [a native shop]. Clothes, shoes, perfume, powder, and nice underwear were the number one items in hunting for a man. I let myself be invited out with others or suffered hunger. The first requirement was a separate room, or a furnished (converted) garage, and a lanclady who did not look too closely. Aware of my own physical attractions, I was always trying to get rid of that viper: my inferiority complex.

I had no trouble getting dates. I experienced pride and great feeling of victory when on the dance floor I moved from one to the other. Age made no difference: anyone between 22 and 55 was good, so long as he was Dutch. I knew that many of them were married--still I tried to catch them. Divorces were common. And yet, I had had no sexual relationships. I was way behind. Many Indo girls, as early as sixteen, had abortions with djamu [a native herb] which could be bought for a dime. ${ }^{4}$ Dutch girls, on the other hand, became pregnant--or went somewhere on vacation. Abortions by doctors, for instance, were performed in Bandung and Semarang.

War was in the air. Time was pressing. By the time the war would be over, we would be over 21 --old maids. ${ }^{5}$ A terrible thought! Hurry! Hurry! By now I wanted to give myself completely to someone--full of warmth and with my whole love. Gone was the period of desire alone. Many of my friends married. The job held by a prospective Dutch husband was taken into consideration by all of them. Age was no factor; they got married and that was the important thing. But for me it could not be

4. Although the medical basis for the use of many indigenous herbs has not been fully explored it has been found that an Indonesian herb, Kumis kutjing (Orthosiphon grandiflorus Bold), contains important medicinal elements. For a general discussion see H. A. C. Boelman, Bijdrage tot de Geneeskruidcultuur in Nederlandsch Oost-Indiêe (Leiden: 1936).

5. A typical ex post facto statement. In 1941, few assumed that the war would last that long. 
for money or position alone, I must love the man and he must appeal to me. Even the animal chooses. I could not bear a child from a man I did not love. The memory of our babu and her delivery came to my mind--she loved her husband, I was sure of that. A woman can be in love several times, but only once completely.

I established contact with men by correspondence. Everything went fine until we met, then they ignored me or made me feel. that $I$ was an Indo. A blind man once loved me--until the first meeting after his successful operation. Then his face turned pale and registered disdain--he was a Dutchman, I an Indo. I had conversations with men by phone. They were curious how I looked--according to my name and manner of speech, I was blond, sweet, and cordial! Then the meeting and they quickly left and even let me pay for my own drink or did not return. The Germans were the most indifferent to color. They did not mind marrying an Indo girl when they loved her. Two Germans desired me as a wife, but I had no interest. There was no love, but still I was torn by the dilemma. One voice said: "This is your chance, grab it!" The other one said: "But I don't love them." But my mind was made up: no love, no marriage. Frenchmen had no interest in marriage. I knew three of them; they only wanted sexual relationships. The British were perfect lovers. They never displayed prejudice openly to me and never talked about it. It was a good relationship with them, also sexually with precautions. But marriage or engagement was out of the question. They took care that no one else of the British community ever saw them in the company of a half blood. They always knew, with the instinct of the hunting dog, how to avoid those places or movies where their friends might be. I also suspected that even when they saw their friends they respected each other and did not greet each other. They never offered any chance for marriage, but I still preferred them. They were cool and controlled, but very sweet and fiery when alone with a woman.

This is shameless, awful, awful! Any Indo woman would rather bite off her tongue than write these things down. Still it is important. I hope you will see it in the proper light.

The relationship between Indo girls and Dutchmen was often painful and perverse. It was the same with the married ones. One was made to feel clearly that one was only an Indo and that what they did not dare to do with their adored Dutch wives they would carry on with Indo girls. They were rough and shameless. Many of them were married, but kept it secret and engaged themselves to Indo girls without qualms. Many girls were actually seduced and became scared of the Government's Moral Police. I myself lied to the Police that I was already 21 . How confused and abused I was, but still I had to succeed.

I really wanted to love. I swear that if I later have to stand in judgment I can say that I never looked at a man's 
position or his handsome face. I only wished for a white man who did not see that I was a half blood and who would give me children. That isn't bad, is it? I was confused but still it was worthwhile.

Before the war, abortion was easy; but it was only done when one had too many children, when one already had older children, or if the fellow didn't want to marry. In my case, admitting it honestly, I had seven or eight abortions before marriage; one was by my present husband upon his insistence before we were married. As far as I know, an Indo girl has never consciously persuaded a man to sleep with her and get a child to pressure him into marriage. None of my friends ever did it. On the other hand, I knew three Dutch women at that time who got married that way. I know that homosexuality existed among some girls. It did not exist among the boys. Their mothers took care of that by seeing to it that a cute young babu was employed in the household. This was all conducted with the utmost discretion. Both the dear son and the babu kept it to themselves.

The Indo women knew that their husbands very often gave the babu her share of attention. They did not think too badly of this, because after all it was only the babu. Then, too, what one didn't know, did not hurt. Others prevented this practice by employing older babus. According to Indo women, sexual desire in [Indonesian] servants is extinguished by their fortieth year. Among Indo women, it is considered unfit to sleep with a man--not even their own--after or during the menopause. Then Daddy must go to the babu, if he wants to, but for goodness' sake, don't let the wife find out!

Many Dutch boys and men were subjected to guna-guna [b]ack magic]. Now don't sneer! The men were made groggy by the constant use of herbs and sometimes excrements of the woman's body, mixed with their food or drink. This is no story. It is something very important--even though many sneer about it--in breaking down and confusing will power. It absolutely, to put it bluntly, forces the person in such a violent way, to continue intercourse that, combined with all that guna-guna, he is spiritually broken for the time being. I saw it used much by muntjies, the wives of regular soldiers. ${ }^{6}$

6. In contrast to the extensive literature on voodoo, little is available in English concerning Indonesian black magic. The topic has not been ignored, however, by Dutch and Eurasian authors. See, for example, P. A. Gaum, Goena-goena (Leiden: 1889); L. Couperus, De Stille Kracht, 2 vols. (Amsterdam: L. J. Veen, 1900); H. A. van Hien, De Formulieren voor de Stille Kracht (Weltevreden: 1924); and the various detective novels by the Eurasian author Ucee (pseudonym of S. H. Coldenhoff). Although few educated Eurasians admitted a 
The Indo felt himself above the Javanese. I have never heard a Dutchman abuse servants and inferiors with such foul language as did the Indo. The latter has complete command of the language. What did Dutchmen say when they were angry? Damn it! Damn it! Some were called Tuan Per Dom [Mr. Damn It]. The Javanese forgave them (the Dutch) much when they were drunk and spoke in this manner.

There definitely are three groups of Indos. In the first group are those who are born with quite white features. Many of these have moved as far away as possible from their families-even as far as South Africa or Holland and have never admitted that they were Indos. Others in that group remained in the Indies but swore that they were not Indo and broke with all their family members, even their own parents. To the second group of Indos belong people like myself. To the third group belong the people you have seen in the relocation center and those Indos who are still in the Indies at present. The group you see in the relocation center would be better off if they had not been born halfbloods, but rather as either European or native full bloods.

I never deny that $I$ am an Indo and I let the word roll off my tongue with real zest. I taste it, it is delicious. My husband is ashamed of it. Less than six months ago, he denied to guests from abroad that I was an Indo. How does that affect me? It hurts me. I love him; he is a real Dutchman, a good average Dutchman. He doesn't care very much for the children although he does like our youngest very much. She is a French type and absolutely European [in appearance]. However, she turned out to be retarded and since we discovered that, I really never have known exactly what he thought of her. Toward our oldest one, who is very sweet and feminine, really softness itself, he is indifferent and often hard. He sees her softness as indolence.

My husband is not my great love. The person whom I still love with my whole soul is a Scot. You may ask whether I can stand my husband, then? I have a big warm heart, and I am also too intelligent and practical to dream and bemoan my fate.

My husband hates my family. He despises my sister who is soft and very impractical, but good; the nice type of Indo woman.

belief in guna-guna it is of interest to note that Onze Stem, the party journal of the Indo-Europeesch Verbond (Eurasian League), carried without comment a series of articles by Hitzka ("Over de Magie in Indië," Vol. XI, 1930, pp. 1073 ff.) on the subject. In one of the articles it was emphasized that "the human hair and nails contain the most vital force of all parts of the human body," and that they, therefore, should never be thrown away "indifferently" (ibid., p. 1163). 
He also dislikes my Indo brother-in-law who is a real Dutchhater. My husband does not wish to have my old mother come over from Indonesia, although the money to pay for her transportation waits in the closet. He wants no Indo relatives around the house. Yet, he loves me very, very much. I am not being facetious. You don't know how guilty I sometimes feel. But it is worthwhile, this marriage between me and the Dutchman. There are many more rather successful marriages like this.

The Indo wife is good and really loves her children. She unfolds her positive qualities much better in her maternal love than in her marital and sexual life. Although she sometimes can be handy she remains impractical. She can't work efficiently so that trying to do the most work in the least time is impossible. She loves coziness. She may scream at her husband and her children and spank the latter, but on the other hand, she can be tenderly affectionate. If she has had a fight with her husband, for example, she will try to make herself wanted in the evening. She might take a bath in rose and melati [jasmine] water, powder herself, and perhaps invite a family she knows well to help her cajole her husband.

The Indo girl knows, without being offensive, how to set a man afire. I find her more experienced in this than her honored French sister. The Dutch woman misses the beautiful gait of the Indo girl and the gift of the game of love. The Indo man can't easily marry a Dutch girl; but, nowadays, when he gets the chance to do so in Holland, he is absolutely content. The satisfaction of victory is something like the pleasure of my father which I mentioned before.

The Indo is easily irritated when he is in a group of Dutch boys and girls. He quickly becomes mata gelap [runs amuck]. The Indo also loves to sulk. Aren't you familiar with the hated tinkas [caprices] which annoyed the Dutch so much? On the other hand, an Indo father loves his children very much. He generally is more refined than the average Dutchman and more sensitive.

A Dutchman did not take a Javanese woman quickly when he could get an Indo. Many rich Dutchmen had Indo women and girls living in little apartments. Dutch daddies did not hesitate to seduce Indo friends of their daughters. Some Dutch women had relations with their djongos or their driver. Doctors often lived with Menadonese, Indo, and Javanese nurses. During the Pacific War, the social gap between Indos and Dutch grew even wider, almost approaching that existing between the British and the Indo girl: Dutch women were game for handsome Japanese. Dutch women find our Indo babies adorable with their doe-like eyes and their dark hair. Babies, that is, mind you.

No half bloods, that is my slogan! 
Can you understand it when I say: East is East and West is West? Yes, this symphony--the white, high and light tones which ring and ascend to Heaven--that is the West. And the dark tone--heavy and poor--just touched discord in this symphony, that is the half blood. Notice, I do not say the East.

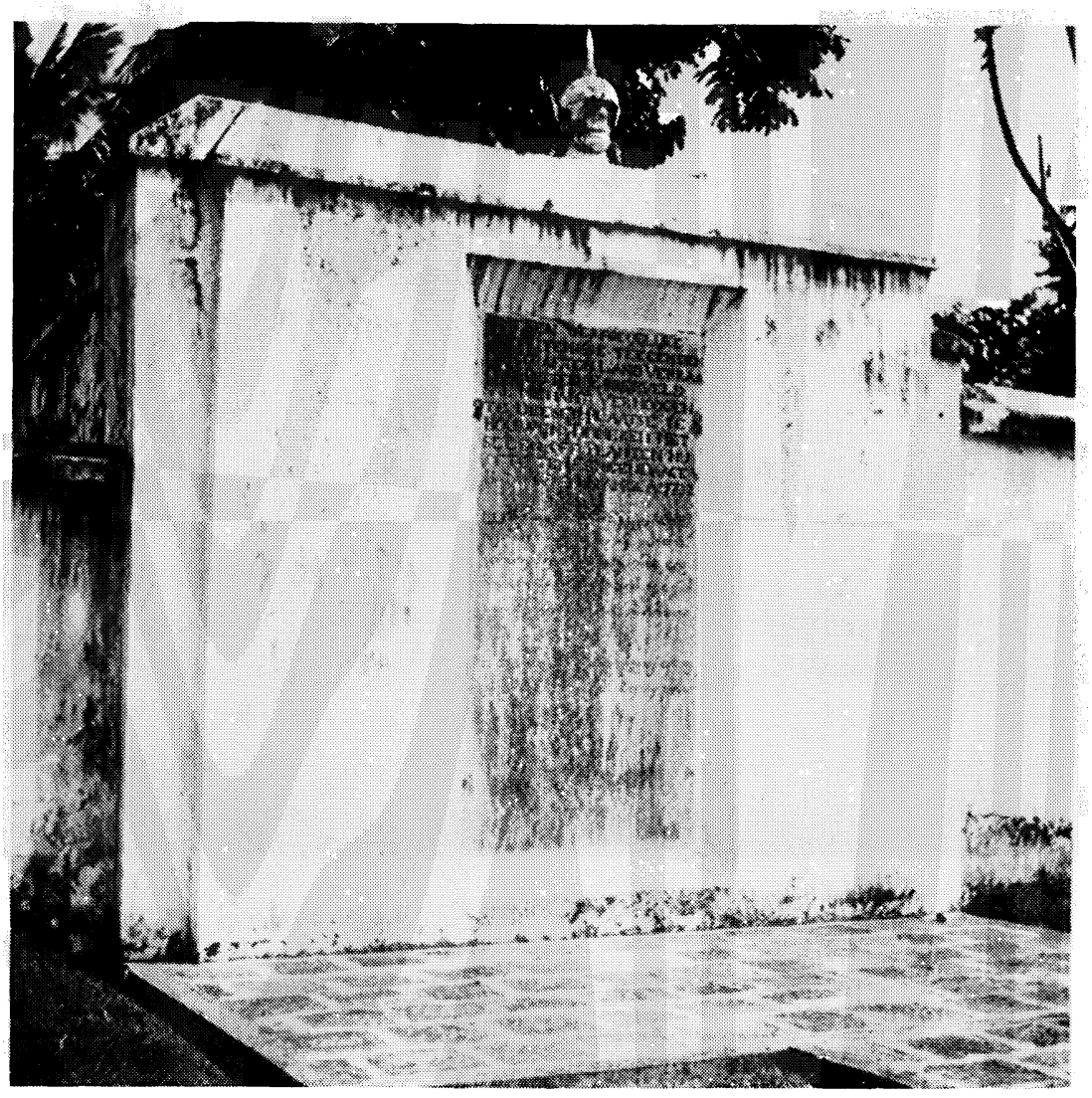

The monument in Old Batavia erected to commemorate Pieter Erberveld a Eurasian who, in cooperation with a Javanese nobleman, planned an indigenous uprising aimed at overthrowing Dutch rule in 1721. The deep-rooted Dutch concern about the possibilities for Eurasian-indigenous alliances against their regime is expressed by the severity of the monument and its inscription. On top is a skull, pierced by an iron spear as a sign of dishonor, and underneath a plaque engraved: "In loathsome memory of the punished traitor Pieter Erberveld, no one may build, carpenter, lay bricks, or plant on this place either now or on any future day. Batavia, April 14, 1722." Photo: Claire Holt, 1936. 


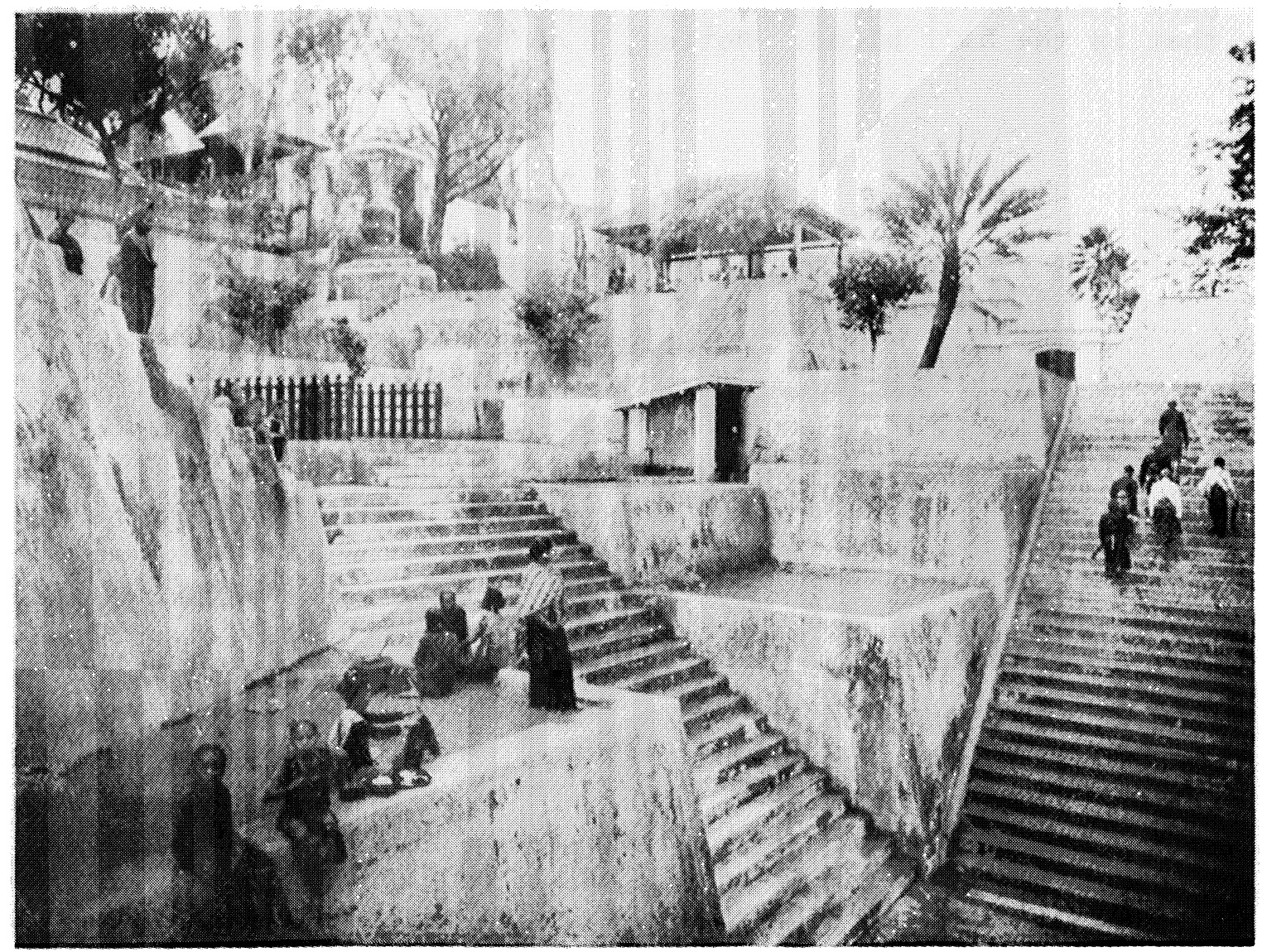

The holy burial grounds at Imogiri, between Jogjakarta and Solo, containing the grave of Sultan Agung I, greatest figure of the Mataram dynasty. Despite the events during Jasadipura's time which split the ruling line into two courts, Jogjakarta and Surakarta, both families continued to bury their dead here at Imogiri. Photo: Tassilo Adam, in Nederlandsche-Indië Oud en Nieuw, February 1928. 